\title{
The Application of Internet Technology in Vocational Education Informatization
}

\author{
Hong Yan* \\ Chongqing City Management College, Chongqing 401331, China \\ *Corresponding author: Hong Yan, 2582642987@qq.com
}

Copyright: () 2022 Author(s). This is an open-access article distributed under the terms of the Creative Commons Attribution License (CC BY 4.0), permitting distribution and reproduction in any medium, provided the original work is cited.

\begin{abstract}
Under the background of the new era, higher vocational colleges should improve education in line with the characteristics of social development, so as to improve education quality and promote the development of education informatization. In regard to this, teachers and teaching managers should strengthen the research on internet technology, improve the application level of internet technology, and appropriately modify the mode of teaching, so as to create favorable conditions for the application of internet technology in higher vocational education.
\end{abstract}

Keywords: Internet; Vocational education; Informatization

Online publication: February 22, 2022

\section{Introduction}

China has been committed to educational reform, in which education informatization is one of the key contents of the reform. It emphasizes that in the actual process, all levels of education should make full use of computer network communication, multimedia, and other channels to deeply explore the modern information technology education model. For higher vocational colleges, employment is the main goal of education. This determines the education needs of students, which include the cultivation of students who are able to meet the needs of the society and social development. With the help of the "Internet Plus Occupation Education," education informatization has become an inevitable way to train high-quality talents.

\section{Significance of informatization in higher vocational education}

\subsection{Meets the requirements of social development}

The scope of application of information technology in society is expanding day by day. As a talent training base, schools should turn their attention to the lifelong development of students. Under the background of "Internet Plus Occupation Education," schools should make full use of the characteristics of the times to improve the mode of teaching, break through traditional teaching concepts, and maximize the potential value of modern technology, so as to provide comprehensive talents for the society.

\subsection{Promotes the training of practical talents}

Under the background of "Internet Plus Occupation Education," the teaching of information literacy in colleges and universities can create favorable conditions for the cultivation of students' practical skills. In 
the teaching process, information technology does not only enrich students' knowledge base, but also expand their vision. Therefore, in teaching related majors, the content of the teaching materials should be emphasized in a comprehensive manner.

\section{Development of vocational education informatization under the background of "Internet Plus Occupation Education" and the application of internet technology in education informatization}

3.1. Development of vocational education informatization under the background of "Internet Plus Occupation Education"

\subsubsection{Faculty}

The strength of teachers can be discussed from two aspects: teachers' teaching ideas and the utilization level of information technology. At present, in higher vocational teaching, teachers are yet to break through the traditional teaching concept and focus on teaching materials; that is on how to explain the contents of the teaching materials clearly, while disregarding the cognitive law of the recipients - the students ${ }^{[1]}$. At the same time, there are differences between the education received by teachers before entering higher vocational schools and that of the current era. The application of information technology is uncommon, so there is no effective way to improve the level of information technology. In this environment, there is an urgent need for more in-depth analysis of teachers in higher vocational education.

\subsubsection{Mode of teaching}

Under the background of "Internet Plus Occupation Education," the status of practical teaching is increasingly highlighted. However, in the actual teaching process, the teaching of theory and practice still faces obstacles, such as the lack of professional supervision over the cooperation between schools and social industries, and the difficulty in expanding capital channels. In this environment, the modernization of the mode of teaching has fallen into a deep dilemma, which greatly hinders the informatization of higher vocational education.

\subsection{The application of internet technology in education informatization}

The status of network teaching in modern education has become increasingly obvious. It is a new form of education based on computer technology, network technology, and communication technology for knowledge transmission and learning. Network education represents the effective use of advanced technology and the practicability in modern distance education ${ }^{[2]}$. It is the mainstream mode of development of modern distance education. Its advantages are discussed below.

\subsubsection{Maximize the use of various resources}

All kinds of educational resources span the limitations of space and distance through the network, making school education an open education that can radiate beyond the campus. Well-known schools should give full play to their disciplinary and educational resource advantages, share the best teachers and teaching achievements through the network, promote regional educational exchanges, as well as enable students in underdeveloped areas to also receive high-level education.

\subsubsection{Five "any" and active learning}

The application of internet technology in distance education is characterized by anyone, any time, any place, any chapter, and any available courses. The convenient and flexible five "any" of network education 
directly reflects the characteristics of active learning and fully meets the basic requirements of developing modern education as well as lifelong education.

\subsubsection{Two-way interaction and real-time interaction}

The communication between teachers and students as well as among students themselves occurs in an allround way through the network, shortening the psychological distance between teachers and students and increasing the opportunities as well as scope of communication between teachers and students. Through the statistical analysis of the types and number of questions raised by students using the computer, teachers can understand the doubts, difficulties, and problems encountered by the students in learning, thus enabling them to guide students more pertinently.

\subsubsection{Personalized teaching}

In network education, using the unique information database management technology and two-way interaction function of the computer network, the system can realize a complete system tracking record of each student's personality, learning process, and learning stage. On the other hand, the teaching and learning service system can put forward personalized learning suggestions for different students according to the recorded personal data. Network education provides a practical and effective way for personalized teaching ${ }^{[3]}$.

\subsubsection{Automated remote management}

The functions of automatic database information management and remote interactive processing of the computer network can also be applied to the teaching management of network education. The consultation, registration, payment, course selection, inquiry, student status management, homework, and examination management of remote students can be completed by means of remote interactive network communication.

\section{Problems of vocational education informatization that need to be solved in the era of "Internet Plus Occupation Education"}

Under the background of "Internet Plus Occupation Education," most vocational colleges have carried out educational reform work, in which many of them have achieved success. However, from the current social development demand for talents, higher requirements have been put forward for higher vocational education teaching. There are many deficiencies in the construction and implementation of the talent training mode, teaching mode, and training system, hindering the talent training process ${ }^{[4]}$. For some vocational colleges, their teaching platforms, modes, methods, and means are not innovative enough and do not keep pace with the times, thus requiring these schools to conform to the reality, actively improve their education and teaching system, as well as build an education and teaching system in line with the requirements of the times. Only in this way can they make basic preparations for the follow-up education and teaching reform. The core goal of higher vocational education is to teach students basic knowledge, cultivate professional skills that are required for work, promote the transformation of students to become applied, practical, and skilled talents, as well as encourage them to contribute to the development of various industries in the society. However, at present, the problem of students in higher vocational colleges is that their basic skills are relatively weak. At the same time, their comprehensive quality is low, which brings resistance to the cultivation of skilled talents and puts forward many challenges to the routine education and teaching of teachers of various majors in higher vocational colleges.

In the internet era, various information technologies have come into being, prompting modern 
vocational education to enter a new chapter. Under this background, higher vocational colleges, as a place for vocational talent training, have also ushered in new development opportunities. With the integration of the internet, the education and teaching concept of vocational colleges has been reformed to a great extent, and a variety of new teaching methods have been derived, including online and offline education and flipped classroom, which have improved the overall level of education as well as teaching in higher vocational colleges ${ }^{[5]}$. These new education and teaching methods completely break the indoctrination and cramming style of teaching under the previous examination-oriented education, actively promote the educational concept of the new curriculum reform, highlight the students' status as masters of the classroom, and "return" the classroom initiative to students. In classroom teaching, teachers can greatly enrich the teaching content by using various teaching methods with the help of the internet and teaching platforms. At the same time, they can also expand students' vision of acquiring knowledge, which plays an important role in improving their learning ability and professional skills, and eventually promote the education and teaching reform of higher vocational colleges.

\subsection{Infrastructure}

The application of information technology requires supporting equipment. At present, higher vocational education is equipped with basic multimedia equipment, but the multimedia system lacks pre-evolution construction, and the application of its operation interface has certain limitations. At the same time, more in-depth research on the internet is required. The application of information technology should not only be restricted to teachers, but also take into account the needs of students.

\subsection{Construction funds}

In order to promote teaching reform, financial support is required to provide material support for the implementation of relevant teaching measures. However, due to the lack of scientific management of school funds, the application of information technology is relatively slow. The development of the era of "Internet Plus Occupation Education" has put forward new requirements for vocational education informatization. It does not only need to enhance the application level of students' professional knowledge, but also to take into account of the requirements of occupation development for students. Among them, the cultivation of practical skills that mandates professional equipment requires a lot of capital investment.

\subsection{Relationship between schools and the society}

Under the background of "Internet Plus Occupation Education," the relationship between schools and the society is becoming increasingly intimate. Although school-enterprise cooperation has certain development foundation, in the past, cooperation is limited to fund cooperation, and it lacks technical cooperation. Therefore, it is necessary to strengthen the research on the cooperation between schools and enterprises as well as optimize the communication between schools and the society, so as to carry out vocational education in an all-round way and promote the development of teaching modernization in colleges and universities.

\section{Development strategy of vocational education informatization under the background of "Internet Plus Occupation Education"}

\subsection{Assuming the information platform as the teaching channel}

At present, the communication between students and teachers in higher vocational education is mainly through social software, such as WeChat, which carries certain limitations. In addition to that, teaching management depends on class groups, which is not conducive to the application of information technology 
[6]. In regard to this, information platforms can be used as teaching channels in the teaching process. Therefore, creating a professional teaching management platform that refers to the online teaching mode will be beneficial. Assuming the information platform as a teaching channel is a convenient method for the construction and transmission of teaching resources. This will strengthen the integrated management of teaching. On this basis, it is then possible to create a school website and a good environment for vocational education. At present, the rate of resource utilization of school websites is low in view of the lack of effective guidance in the teaching process. Therefore, schools should publicize their school websites through the electronic screen to attract students' attention, so as to improve the utilization of information resources.

\subsection{Optimizing school-enterprise cooperation}

Industrial integration, which is the combination of production and professional teaching, the expansion of teaching space, the strengthening of technical cooperation between schools and enterprises, as well as the extension of school resource channels, can cultivate the professional quality of students. Therefore, the teaching mode of one major that corresponds to a specific industry can be adopted. On the premise that they have accumulated a certain theoretical basis, students can then enter the production line for practice, so as to promote the mutual improvement of theory and practice. At present, the utilization rate of school education is low, and the mismatch between major and employment is serious ${ }^{[7]}$. The teaching mode of industrial integration can deepen students' understanding of their major and improve the application effect of school education to a certain extent. When implementing the teaching mode of industrial integration, it is then possible to deeply analyze the school-enterprise relationship and further optimize school-enterprise cooperation. For example, schools can provide factories for enterprise use, while enterprises can provide equipment for school use. At the same time, teachers can strengthen the theoretical basis of enterprise talents, while enterprise talents can improve the practical system of teachers and students, so as to achieve a win-win situation between schools and enterprises.

\subsection{Improving the internet infrastructure and expanding the scope of application of information technology}

In the development process of vocational education informatization, schools tend to emphasize on the informatization of teaching resource construction but neglect the informatization of teaching resource utilization. Schools should improve the internet infrastructure and expand the scope of application of information technology. For example, a campus network can be added in the classroom for students to use. In order to promote the rational utilization of campus network resources, teachers can strengthen the teaching patrol, enrich the teaching content, and stimulate students' interest in learning. Through the campus network, students can better accept various teaching methods, such as the application of micro class, which can effectively improve the teaching quality. However, the one-to-many teaching method limits the development of micro class to a certain extent. At present, the popularity of smart device is high. Therefore, this advantage can be used to carry out one-to-one teaching in the form of micro courses. In this process, teachers can establish the theme according to the teaching content, encourage students to use smart devices to collect data within 5 to 10 minutes, and carry out classroom communication on this basis, so as to give full play to students' initiative and cultivate their information literacy.

\subsection{Optimizing practical operation assessment and strengthening students' professional quality}

Under the background of "Internet Plus Occupation Education," the concept of "talent" has also been given more meaning. It does not only include professional knowledge, but also communicative competence, 
emotional management skills, crisis response capability, etc. In regard to that, it is possible to create a virtual situation through information technology to assess students' practical operation. In this process, targeted design can be carried out according to professional content. For example, at present, the application of virtual reality (VR) technology has been strengthened in the society. When conducting practical operation assessment, VR technology can be used to add possible problems to practice scenes, and the assessment can be conducted from two aspects (psychological quality and professional operation) to strengthen students' professional quality.

\section{Innovative practice of education informatization}

\subsection{Coordinate the development of undergraduate colleges and universities with education informatization}

For the transformation, upgrading, and development of undergraduate colleges and universities, it is necessary to constantly strengthen their comprehensive school-running strength, pay special attention to the synchronous development of education informatization, improve the internal driving force for development, and prevent education informatization from becoming a shackle that hinders the rapid development of colleges and universities. Building morality and cultivating people is the fundamental task of colleges and universities. The purpose of running a college or university in China is to provide top-level talents for the social development in China and better serve its social and economic development. It should be understood that all works in colleges and universities should be centered around the central work. The "Internet Plus" education informatization construction in colleges and universities is no exception. When designing the overall development plan and formulating long-term development goals, schools must organically combine education informatization with teaching, scientific research, and management. The construction of education informatization in colleges and universities is not the responsibility of one department or several departments, but rather, a way of thinking and technical means to digitalized and interconnect the overall work of colleges and universities. The education informatization system should not be designed in isolation. It is necessary to build an information-based campus with outstanding characteristics in line with the school's own characteristics and develop in coordination with various undertakings of the school.

\subsection{Promote the construction of education informatization under the guidance of technological application}

After all, the purpose of education informatization in colleges and universities is to better serve education and teaching as well as improve the quality and efficiency of education. Therefore, it is worth thinking about how to better implement the design so that the majority of teachers and students can experience the technical dividend of high technology.

(1) Build the design framework and set clear goals for campus information construction.

(2) Focus on the implementation of information construction as well as the process and effect of practice, and integrate technical means into daily teaching management.

(3) Establish and improve the evaluation mechanism of information construction, and regularly evaluate the effect of information construction through feedback.

\subsection{Build an information-based classroom through teaching activities}

Under the background of "Internet Plus," the use of internet in higher education has gradually formed platforms, systems, resources, and software for online teaching. In today's information society, mirroring 
the traditional classroom teaching model will not fully meet the needs of contemporary college students. Teachers are required to have internet thinking, master certain multimedia and internet technologies, as well as present the syllabus to students using the internet model. The introduction of excellent teaching courseware and various forms of micro courses encourage college teachers to go beyond the limitation of the blackboard. Through internet technology, teachers can cross the constraints of time and space, communicate with students, and answer questions by using various multimedia channels, such as WeChat, QQ, and other software ${ }^{[6]}$. The application of new technologies and methods can abolish the one-way transmission dominated by traditional preaching, stimulate students' interest in learning, and improve classroom efficiency.

\subsection{Promote the construction of an information-based classroom through teaching evaluation}

Through campus information construction, the data of various departments can be interconnected, forming a big data model and providing a large amount of data that can be analyzed and evaluated, which is conducive to the integration of students' achievements, tracking students' learning process, and evaluating them. Another feature of education informatization is the interaction between students and teachers. Teachers can compile students' feedback on the learning effect of this course through big data and then jointly carry out discussions and exchanges, so as to better promote the common progress of both teachers and students.

\subsection{Pay attention to the construction of teaching contents and resources in education informatization}

With the development of the times and technological progress, the internet does not only provide educational resources, but also rich teaching materials and teaching technical means. Traditional teaching is realized through blackboard writing or transcribing blackboard contents to PowerPoint slides, which is not enough to attract students' interest in learning. Nowadays, with the continuous development of computers and animations, audios, GIFs, short videos, and even 3D virtual simulation videos can be added to the slides used for teaching. This new information-based teaching content and form attract college students, as it provides strong subjective motivation to understand the teachers' curriculum content, thus doubling the teaching effect with half the effort. Students will learn under the experience of new technologies. Teachers are encouraged to base themselves on the internet, make full use of the advantages of mobile internet, constantly build and accumulate information-based teaching contents, collect multimedia knowledge base required for certain courses, guide students to use mobile terminals to learn and consult relevant materials, make learning easier, as well as achieve the effect of integrating "fun" into teaching.

\section{Conclusion}

Colleges and universities are encouraged to continue to build online learning platforms. Through the development and construction of online courses, such as Mu class, classes by well-known teachers, interesting elective courses, and open class videos, those with rich optional categories, reasonable discipline structure, and meet the needs of contemporary college students should be continuously offered, so that the limitations of the classroom can be broken, students' horizon can be broadened, and the teaching quality of teachers can be improved while continuing to build a high-quality network information classroom.

\section{Disclosure statement}

The author declares that there is no conflict of interest. 


\section{References}

[1] Nan X, 2016, "Internet +" Vocational Education: Logical Connotation, Formation Mechanism and Development Path. Vocational Education Forum, 2016(1): 7-10.

[2] Su Z, Cheng L, Kong W, 2015, Analysis on the Scientific Development of Vocational Education from the Perspective of "Internet +". Journal of Mudanjiang Normal University: Social Science Edition, 2015(5): 4-8.

[3] Zhang F, 2017, Construction and Application of Vocational Education Teaching Resource Database Under the Background of "Internet +". Vocational And Technical Education, 2017(8): 13-16.

[4] Che M, 2015, Internet +: Challenges and Opportunities for Vocational Education. China Vocational and Technical Education, 2015(22): 9-11.

[5] Hao T, Shi W, 2017, New state of Vocational Education Service Under "Internet +": Connotation, Goal and Direction. Modern Education Management, 2017(6): 5-9.

[6] $\mathrm{Hu} \mathrm{C}, 2015$, Research on Marketing Higher Vocational Education Under Mobile Internet. Market Weekly, 2015(1): 3-4.

[7] Shen Y, 2017, Research on the Integration of Agricultural Vocational Education and "Internet +" Under the New Situation. Agricultural Science and Technology: Zhongxunjian, 2017(11): 2-5. 